\title{
Speech of H.E. Mr. Nguyen Hung, Ambassador Extraordinary and Plenipotentiary of Socialist Republic of Vietnam to the Republic of Poland on the occasion of $76^{\text {th }}$ anniversary of the National Independence Day (September 2, 2021)
}

\author{
Выступление Е. П. господина Нгуен Хунга, Чрезвычайного \\ и Полномочного Посла Социалистической Республики \\ Вьетнам в Республике Польша по случаю 76-й годовщины Дня \\ национальной независимости (2 сентября 2021 г.)
}

H.E. Minister Arkady Rzegocki, Head of Foreign Services,

Ministry of Foreign Affairs of Poland,

H.E. Minister Pawet Szrot, Chief of the Cabinet of the President, Ambassadors, Heads of Diplomatic Missions,

Distinguished Guests,

Ladies and Gentlemen,

It is my great pleasure to have you join us tonight to celebrate the 76th anniversary of the founding of the Socialist Republic of Vietnam. On behalf of all the staff at the Vietnamese Embassy in Poland, please allow me to extend the warmest welcome to all the distinguished guests and express our sincere gratitude to all the Polish friends, international fellows and Vietnamese community in Poland who have been supporting Vietnam's development and fostering the growth of the relationship between our two countries. 
Ladies and Gentlemen,

As you know, September 2nd is for us an absolute symbol of all the values on which modern Vietnam rests. Vietnamese people with the aspiration of Independence - Freedom - Happiness overcame all obstacles to strive for national independence, for prosperity, peace, cooperation and development in the region and over the world. Over the 35 years of economic reform, GDP of Vietnam has increased by 12 times. The United Nations recognized Vietnam as one of the leading countries in realizing the Millennium Development Goals, especially on poverty reduction, gender equality, healthcare and education. With the Five Year Economic and Social Development Plan (2021-2025) and the Ten Year (2021-2030) Economic and Social Development Strategy commencing this year, Vietnam strives to be a developing country with modern industry and high middle income by 2030 .

On the development path, Vietnam has established a comprehensive and strategic cooperation framework with 30 partners; become an active member of many major organizations and forums such as ASEAN, APEC, ASEM, WTO, UN... and signed and implemented 16 new-generation free trade agreements. As a responsible non-permanent member of the United Nation Security Council for the tenure 2020-2021, Vietnam is demonstrating its strong commitment to stay united with the international community to solve the issues shared by humankind.

Looking ahead, I'm fully confident about the progress of Vietnam in strengthening the economy as well as in enhancing the position and stature in the international arena.

\section{Ladies and Gentlemen,}

Our national day is an opportunity to look back at current achievements related to the bilateral relations between Vietnam and Poland, which are based on a more than 70-year-long history of diplomatic relations. Vietnam always considers Poland as a top partner in Central and Eastern Europe. Vietnamese economic relations have great potential, they are developing successfully and I am happy that the trade exchange between Vietnam and Poland in the first 7 months of 2021 has reached 1.5 billion USD, increased by $34 \%$ despite of the crisis caused by the Covid-19 pandemic. I do believe 
that the sound economic foundation will bring two countries a realistic hope on the bright future.

During the current challenging time, the world needs solidarity more than ever before. We highly appreciate and cherish the active role of Poland in helping other countries to fight the COVID-19 pandemic. We always remember the generous and spontaneous support of Poland on vaccines and medical equipments to Vietnam. This morning, 70 tons of medical goods as humanitarian aid of Poland have been dispatched to Vietnam. It makes our ceremony today much more meaningful. There is a saying in Polish that perfectly describe our mutual support in the current fight against Covid-19 "przyjaciól poznaje się w biedzie". I am certain that the traditional relations of friendship and multifaceted cooperation between our two countries will be even more advanced and more efficient.

\section{Ladies and Gentlemen,}

In this solemn but cozy atmosphere, I:

- Wish the prosperity and happiness for us, Polish \& Vietnamese people,

- Wish the best for our traditional and multifaceted relationship,

- Wish the good-health and happiness for every distinguished guest who presents today.

Thank you so much. 